\title{
Recent Trends in the Supply and Demand of Volunteers
}

\author{
Marina Schenkel1, Paolo Ermanoํ, Domenico Marino² \\ ${ }^{1}$ DIES, Udine University, Udine, Italy \\ ${ }^{2}$ Pau Department, Mediterranea University of Reggio Calabria, Reggio Calabria, Italy \\ Email: marina.schenkel@uniud.it, paolo.ermano@uniud.it, dmarino@unirc.it
}

Received 16 May 2014; revised 10 June 2014; accepted 20 June 2014

Copyright @ 2014 by authors and Scientific Research Publishing Inc.

This work is licensed under the Creative Commons Attribution International License (CC BY). http://creativecommons.org/licenses/by/4.0/

(c) ()

\section{Abstract}

This work aims at describing the trends observed since the beginning of the crisis in the supply of and demand for volunteers. Few works exist that examine this dynamic, for the lack of recent data, and because the study of the demand for volunteers and for volunteers services is still rather undeveloped. Some hints appear that indicate: 1) an increase in the stock of volunteers, but not in every country, 2) an increase in demand for volunteers services.

\section{Keywords}

Volunteering, Economic Crisis, Supply and Demand Side, Welfare State

\section{Introduction}

The recent problems of Public Expenditure in many European countries have led to a downsizing of many public services, including education, health, social services, culture and sport, or at least their reorganization in terms of funding, pricing, and access policies. The widespread opinion of an inefficient management by the public administration provides further justification for this choice. One of the consequences of the crisis seems to be the emphasis of the polarization between government failures and market failures. However, the idea of minimizing the role of the state is only a partial solution. Indeed, there is a growing recognition that market failures not only persist, but are probably aggravated by the cuts.

A contribution to the solution of this problem may come from the use of two channels: the volunteers and the voluntary and third sector organizations. The third sector can be seen as a form to limit and correct government failures, helping to overcome the unresolved (and often misleading) dilemma between the state and the market.

The main benefits that arise from the increased use of volunteers are two: The first is the direct reduction in personnel expenses; the second is more subtle: a possible increase in the public's appreciation of an organiza- 
tion's mission and social value (be it public or private).

In addition to the question of public finance, another factor has increased the role of volunteers, both from the supply and the demand point of view: rising unemployment. What have this developments done to the extent of volunteerism? This paper aims at formulating hypotheses on these questions, starting from the available data, in Europe and in some European countries, with a special reference to Italy, and imagining what will be the possible evolution of a phenomenon that does not escape the profound changes brought about by the crisis that we are experiencing. After a brief review of the literature (Section 2) some recent empirical evidence will be commented (Section 3) and some interpretations will be presented (Section 4). A discussion of the theoretical and policy implications of the recent trends will be concluded.

\section{Background}

The non-profit sector accounts for more than $4 \%$ of the developed countries GDP [1] [2]. Many theories have tried to explain both the existence of organizations and the motivations of volunteers, since voluntary and not for profit activities appear to be a common feature of human behavior. Menchik and Weisbrood [3] identify the economic reasons for supplying volunteer work. They note that this activity can be seen as both a consumption of a leisure good, and as an investment for improving one's human capital [4] [5]. Since their seminal contribution, volunteering has become the subject of various studies, both inside and beyond the field of microeconomics. The main directions have been identifying the individual benefits from volunteerism, starting from the notion of altruism - the utility gained in contributing to what is perceived as "the greater good". Other directions include motivations for volunteering and the wider social advantages from such activity. The three themes are obviously related.

An issue of fundamental importance is the definition of what constitutes voluntary work. According to Tilly and Tilly [6], it consists of "unpaid work provided to parties to whom the worker owes no contractual, familial, or friendship obligations". The same definition was adopted by the International Conference of Labour Statisticians [7] and has recently been endorsed by the ILO [8]. As pointed out by Wilson and Musick [9], volunteer work, unlike work in the market and in the informal sector, is "un-commodified" and "freely undertaken", explaining why motivations play such a key role in determining what is or not volunteering [10]. The benefits to volunteers are both attitudinal (e.g., greater happiness and satisfaction) and utilitarian (e.g., better health and a higher level of human capital) [11]. The latter includes the opportunity to acquire additional skills. Several studies have found that volunteers receive, subsequently, a positive wage premium [12].

The extent of volunteering is likely to be related to the degree to which it provides satisfaction to volunteers, whether undertaken as a means of consumption or investment. There is evidence that volunteering has a positive effect on household welfare [13] [14]. Andreoni [15] suggests that any type of donation produces a generic public good, associated with social capital and trust [16] [17]. These positive externalities reduce the costs that communities face by increasing the amount of disposable public goods [18]-[20] or by creating new governance structures [21].

An important element is that volunteers might operate where markets are inefficient can produce goods that otherwise would not have been supplied [22], or they can reduce the costs of non-profit organizations, therefore allowing them to survive. For these reasons, many governments support initiatives to increase the pool of volunteers [23]. Among these initiatives, the most famous is the idea of the "Big Society", launched by the Cameron government in 2010 [24]. Weisbrod [25] was the first to highlight that the development of many non-profit organizations stemmed from government failure in the provision of services, a hypothesis recently reaffirmed empirically [26]. Many observers point out that the demand for volunteering has grown considerably before and especially during the crisis, as a result of the retreat of the state and its administration as a producer of public goods and services [27].

The extent to which voluntary work is a complement to or a substitute for paid work has been extensively studied, with mixed results [28]-[30]. Other studies also show that individuals, independently from their role, are more likely to volunteer in non-profit associations than in other types of organization [31] [32].

Finally, another important stream of literature has focused on the effects of employee volunteering, when this activity is supported by the employer [33]-[36]. Even if these arrangements don't involve big numbers of firms/ employees, they are continuously growing in several European countries, due also to the increasing importance of Corporate Social Responsibility [37]. 
On the one hand this sort of approach to volunteerism, which extends the limits of the definition of voluntary work, can lead to consider these forms of participation part of the enterprises' promotion and marketing strategies. On the other hand these arrangements have been a great success, inside and outside the company, both in relation to the possibility of the professional growth of employees, and for the opportunity to open the world of volunteerism to subjects who otherwise would not have the motivation or the possibilities to approach it.

\section{Four Types of Volunteers}

The analysis on the different aspects of volunteering in Europe leads to distinguish four basic approaches: the Anglo-Saxon, the French and Italian, the German and the Swedish ${ }^{1}$.

The Anglo-Saxon model is strongly connected with the civil society and, until the Big Society project launched by the Cameron government, remains isolated from the sphere of public influence. In Germany the term volunteer takes mainly the meaning of an honorary position, and is separated from the labor market. In France and Italy the connections between voluntary and paid work are stronger, and this peculiarity stems from the structural weaknesses in the labor market. The Swedish model is instead correlated with high levels of public investment in welfare [38].

The Table 1 describes the differences in the amount and forms of public spending on welfare in relation to GDP. Overall levels indicate that among the 33 OECD countries United Kingdom, France and Sweden are among the top 10; Germany is at 12th place, and Italy and Spain slide back of the group. Among the forms of public spending, there is a clear predominance of cash in the Anglo-Saxon countries, while Sweden and Denmark show a higher rate of direct services provision, and France instead is notable for a high level of tax relief. Italy has low levels of spending in all three types of expenses. These differences are reflected in the organization, impact and role of volunteering. While in the Anglo-Saxon world these associations have a strong private character, in Sweden the non-profit sector is more developed as a result of high public investment, while in Italy voluntary and Third Sector organization substitute for a substantial under-investment in welfare.

The Swedish type of Welfare is more suitable for the development of social enterprise, while the AngloSaxon or German models are more related to the concept of the self-organization of civil society, with fewer ties to the state and the productive sectors. The Italian model, characterized by the need to face low levels of investment in welfare, leads to the emergence of some innovative designs, such as the concept of Distretto Sociale Evoluto (Social Evolved District) that reverses a traditional concept of welfare aiming to meet only social assistance needs. The Distretto Sociale Evoluto attempts instead to create productive realities outside the traditional areas of personal services, to achieve the dual goal of increasing income and promoting social action [40].

The classification of volunteers into four groups made by Marino, Michelutti, Schenkel [41] can also be interpreted in this context.

The four groups are the following:

Group A: "They want to do something good, to feel useful, but they cannot expect much."

These individuals are essentially people not belonging to the labor force, especially retirees, singles, but also separated and widowers, and have the lowest level of education. The members of this group seem to show the less ideological attitude towards volunteerism. This is the type of volunteer which seems closer to the AngloSaxon model.

Group B: "They want to pursue their ideals in a challenging and rewarding work environment."

They seem to show decision and commitment. They are characterized by the lower propensity to consider volunteering as a way to fill their free time. Moreover for them the organization's ability to meet the needs of volunteers is not important for choosing the organization in which to operate. This type of volunteers is best adapted to the German model.

Group C: "Volunteers with interest."

This group shows the propensity to find a job through the organization in which they operate. They too, like everyone else, are inspired by altruistic attitudes, but seem to be motivated by extrinsic individual inclinations more than the others. This model is prevailing in France, Italy and Sweden.

\footnotetext{
${ }^{1}$ Four types of models in the provision of public services have been distinguished: liberal, corporatist, social democratic and statist. Each of the models points to a different relationship between the state and the market: in the liberal model public welfare is severely limited, thus leaving plenty of space both for profit and non-profit organizations; in the corporatist model Welfare is mainly provided by the State or by "pre-modern" associations, such as the religious ones; universalism in the social-democratic model results from the public sector direct activity, and, finally, in the Statist model, we have both a low level of public provision and the absence of a large third sector [38].
} 
Table 1. Public spending on family benefits in cash, services and tax measures, in per cent of GDP, 2009—Source OECD.

\begin{tabular}{|c|c|c|c|c|}
\hline & Cash & Services & Tax breaks towards families & Total \\
\hline Ireland & 3.26 & 0.82 & 0.15 & 4.24 \\
\hline United Kingdom & 2.46 & 1.38 & 0.38 & 4.22 \\
\hline Luxembourg & 3.51 & 0.53 & 0 & 4.04 \\
\hline France & 1.44 & 1.76 & 0.78 & 3.98 \\
\hline Denmark & 1.63 & 2.27 & 0 & 3.9 \\
\hline Sweden & 1.58 & 2.17 & 0 & 3.75 \\
\hline Hungary & 2.42 & 1.16 & - & 3.58 \\
\hline Belgium & 1.77 & 1.04 & 0.64 & 3.45 \\
\hline Norway & 1.42 & 1.79 & 0.13 & 3.34 \\
\hline Finland & 1.67 & 1.62 & 0 & 3.29 \\
\hline Germany & 1.16 & 0.89 & 1.01 & 3.07 \\
\hline Austria & 2.34 & 0.57 & 0.04 & 2.95 \\
\hline Australia & 1.94 & 0.84 & 0.05 & 2.83 \\
\hline Czech Republic & 1.24 & 0.6 & 0.76 & 2.6 \\
\hline Netherlands & 0.78 & 0.93 & 0.77 & 2.48 \\
\hline Slovak Republic & 1.57 & 0.44 & 0.41 & 2.43 \\
\hline Slovenia & 0.76 & 0.53 & 0.8 & 2.1 \\
\hline Spain & 0.67 & 0.85 & 0.25 & 1.77 \\
\hline Portugal & 1.03 & 0.47 & 0.2 & 1.71 \\
\hline Italy & 0.78 & 0.8 & 0 & 1.58 \\
\hline Canada & 1.12 & 0.23 & 0.21 & 1.55 \\
\hline Poland & 0.75 & 0.33 & 0.45 & 1.53 \\
\hline Japan & 0.51 & 0.45 & 0.53 & 1.48 \\
\hline Greece & 1.02 & 0.4 & - & 1.43 \\
\hline Switzerland & 0.94 & 0.33 & 0.14 & 1.41 \\
\hline United States & 0.11 & 0.59 & 0.52 & 1.22 \\
\hline Korea & 0.04 & 0.77 & 0.2 & 1.01 \\
\hline OECD 33-average & 1.41 & 0.94 & 0.28 & 2.61 \\
\hline
\end{tabular}

Group D: "Voluntary by choice, aware and generous."

This group is dedicated to volunteering with greater continuity. Within this group the inclination towards voluntary activities seems more evident. They tend to show greater empathy in the relationship with users, and do not consider users only as customers, who require a service and get it. The latter group represents the archetype of the volunteer, a kind of ideal profile for which to strive.

\section{Recent Trends in the Supply of Volunteers in Italy and Other European Countries}

The empirical evidence on the evolution of the stock of volunteers derives mainly from the Time Use surveys. There are also European Eurobarometer survey data on volunteering in 2007 and 2011. Numerous other sources do not provide updated data, from which to observe the impact of changing economic conditions on the supply 
and demand for volunteer work. The data contained in this paragraph refer to the number of volunteers, and therefore do not correspond strictly speaking neither to supply nor to demand, resulting from the encounter of the two "functions". It is not possible to establish a priori that the demand for voluntary work is unlimited, and in any case greater than supply, given that voluntary work is free (though not always entirely) with regard to the remuneration of the individual, but its use involves costs related to training, organization, etc. To assign these data mainly to the supply side is more plausible, for two sets of considerations. Apart from the fact that the supply of voluntary work is not unlimited, it is reasonable to think that the output to which volunteer work contributes (education, health, social services, entertainment, essential infrastructure) is not only rationed on the supply side, but also that the demand for these services is able to create its own supply, stimulating the creation of more or less formal organizations dedicated to meet these needs, when they are not completely satisfied by the market or by the State. With this idea in mind, we present the data in the following tables, which are derived from the two sources mentioned above.

Table 2 shows the percentage of Italian population that has carried out some activities related to volunteering in the twelve months preceding the interview, between 2002 and 2012.

Table 2. Persons aged 14 and over who have done volunteer work in the total population aged 14 and over (percentage).

\begin{tabular}{|c|c|c|c|c|c|c|c|c|c|c|c|}
\hline Year & 2002 & 2003 & 2004 & 2005 & 2006 & 2007 & 2008 & 2009 & 2010 & 2011 & 2012 \\
\hline & \multicolumn{11}{|c|}{ meetings in ecological civil rights and/or peace associations } \\
\hline Male & $1.9 \%$ & $2.4 \%$ & n.d. & $2.2 \%$ & $2.2 \%$ & $2.1 \%$ & $1.8 \%$ & $1.9 \%$ & $2.0 \%$ & $2.0 \%$ & $1.9 \%$ \\
\hline Female & $1.6 \%$ & $2.2 \%$ & n.d. & $1.9 \%$ & $1.8 \%$ & $1.6 \%$ & $1.4 \%$ & $1.7 \%$ & $1.6 \%$ & $1.8 \%$ & $1.4 \%$ \\
\hline \multirow[t]{2}{*}{ Total } & $1.7 \%$ & $2.3 \%$ & n.d. & $2.0 \%$ & $2.0 \%$ & $1.9 \%$ & $1.6 \%$ & $1.8 \%$ & $1.8 \%$ & $1.9 \%$ & $1.6 \%$ \\
\hline & \multicolumn{11}{|c|}{ meetings in cultural, recreational or other associations } \\
\hline Male & $9.1 \%$ & $10.4 \%$ & n.d. & $10.2 \%$ & $10.2 \%$ & $10.8 \%$ & $10.3 \%$ & $10.3 \%$ & $11.2 \%$ & $11.1 \%$ & $10.2 \%$ \\
\hline Female & $6.2 \%$ & $7.5 \%$ & n.d. & $7.6 \%$ & $7.9 \%$ & $7.5 \%$ & $7.5 \%$ & $8.3 \%$ & $8.2 \%$ & $8.4 \%$ & $7.7 \%$ \\
\hline \multirow[t]{2}{*}{ Total } & $7.6 \%$ & $8.9 \%$ & n.d. & $8.8 \%$ & $9.0 \%$ & $9.1 \%$ & $8.8 \%$ & $9.3 \%$ & $9.6 \%$ & $9.7 \%$ & $8.9 \%$ \\
\hline & \multicolumn{11}{|c|}{ unpaid activities for formal volunteers associations } \\
\hline Male & $8.7 \%$ & $9.1 \%$ & n.d. & $9.3 \%$ & $9.1 \%$ & $9.6 \%$ & $9.4 \%$ & $9.5 \%$ & $10.5 \%$ & $10.4 \%$ & $10.1 \%$ \\
\hline Female & $7.3 \%$ & $7.9 \%$ & n.d. & $8.5 \%$ & $8.5 \%$ & $8.8 \%$ & $8.6 \%$ & $8.8 \%$ & $9.5 \%$ & $9.6 \%$ & $9.3 \%$ \\
\hline \multirow[t]{2}{*}{ Total } & $8.0 \%$ & $8.5 \%$ & n.d. & $8.9 \%$ & $8.8 \%$ & $9.2 \%$ & $9.0 \%$ & $9.2 \%$ & $10.0 \%$ & $10.0 \%$ & $9.7 \%$ \\
\hline & \multicolumn{11}{|c|}{ unnpaid activities for other types (not volunteers) associations } \\
\hline Male & $3.6 \%$ & $4.0 \%$ & n.d. & $4.0 \%$ & $3.8 \%$ & $4.1 \%$ & $3.8 \%$ & $3.7 \%$ & $4.1 \%$ & $4.5 \%$ & $4.0 \%$ \\
\hline Female & $2.2 \%$ & $2.7 \%$ & n.d. & $2.9 \%$ & $2.6 \%$ & $2.7 \%$ & $2.7 \%$ & $2.5 \%$ & $2.7 \%$ & $3.0 \%$ & $3.1 \%$ \\
\hline \multirow[t]{2}{*}{ Total } & $2.9 \%$ & $3.3 \%$ & n.d. & $3.4 \%$ & $3.2 \%$ & $3.4 \%$ & $3.3 \%$ & $3.1 \%$ & $3.4 \%$ & $3.7 \%$ & $3.5 \%$ \\
\hline & \multicolumn{11}{|c|}{ unpaid activities for an union } \\
\hline Male & $2.2 \%$ & $2.1 \%$ & n.d. & $2.0 \%$ & $2.1 \%$ & $2.0 \%$ & $2.1 \%$ & $1.8 \%$ & $1.9 \%$ & $1.7 \%$ & $1.6 \%$ \\
\hline Female & $0.6 \%$ & $0.6 \%$ & n.d. & $0.7 \%$ & $0.7 \%$ & $0.7 \%$ & $0.8 \%$ & $0.7 \%$ & $0.7 \%$ & $0.6 \%$ & $0.7 \%$ \\
\hline Total & $1.4 \%$ & $1.3 \%$ & n.d. & $1.3 \%$ & $1.4 \%$ & $1.3 \%$ & $1.4 \%$ & $1.2 \%$ & $1.3 \%$ & $1.2 \%$ & $1.1 \%$ \\
\hline & \multicolumn{11}{|c|}{ donations to associations } \\
\hline Male & $16.2 \%$ & $17.0 \%$ & n.d. & $18.5 \%$ & $17.3 \%$ & $17.1 \%$ & $15.8 \%$ & $16.7 \%$ & $17.8 \%$ & $17.1 \%$ & $15.1 \%$ \\
\hline Female & $14.3 \%$ & $16.0 \%$ & n.d. & $17.8 \%$ & $16.8 \%$ & $16.3 \%$ & $15.9 \%$ & $16.6 \%$ & $17.4 \%$ & $16.5 \%$ & $14.4 \%$ \\
\hline Total & $15.2 \%$ & $16.5 \%$ & n.d. & $18.1 \%$ & $17.1 \%$ & $16.7 \%$ & $15.8 \%$ & $16.7 \%$ & $17.6 \%$ & $16.8 \%$ & $14.7 \%$ \\
\hline
\end{tabular}

Source: ISTAT. 
It is clear that the only activity that is actually growing is the free provision of work in favor of voluntary associations. Other types of activities, such as participation in organizations defending human rights, environment, and peace are stable, as well as free labor in favor of non-voluntary associations, the donation of funds, participation in recreation and culture initiatives, while, at least in the male population; the participation in unions is declining. It seems that the new supply of volunteer services, that for the reasons described above is also demand for new services or for services offered before in any other form, is captured by formal organizations of volunteers. This dynamic can correspond to the creation of new entities (associations, cooperatives, etc.), or to the expansion of the existing ones. It is interesting to note that this increase has taken place in recent years, starting in 2010, and then it is plausible to explain it as a result of the current crisis.

While the trade unions decline, although probably accelerated by the crisis, follows a long-term trend, linked to structural changes in the economy as well as historical and social determinants, the other forms of time/funds provision are not affected by the crisis, at least until now.

A considerable heterogeneity in volunteering seems to emerge: on the one hand there are activities corresponding to consolidated choices, seemingly unaffected by fluctuations in (own or others') income. On the other side, the emergence of different, probably innovative, needs and initiatives can indicate the evolution towards new models of volunteerism.

The following table (Table 3), arising from the same source, indicates in different time periods, and with the regional breakdown, the number of people who were actively involved in associations or have worked in voluntary associations. This is clearly a subset of the activities considered in the previous table, which, however, respond better to the definition of voluntary work mentioned in Section 2. The overall increasing trend of voluntary work supply emerges in all the regions (except South, Sardinia and Sicily excluded), but the lack of detail on the forms of activity, and the minor update prevent an accurate comparison with the data in the table above. Interesting regional differences also emerge, who cannot find an immediate explanation, and should be analyzed on the basis of the breakdown by types of activity.

For a comparison with other European countries, it is possible to use as reference the results of the Eurobarometer surveys (Figure 1). We must remember however that the Eurobarometer data are of a different nature, resulting from opinion polls carried out at the European level. Among the Italian respondents, for instance, the

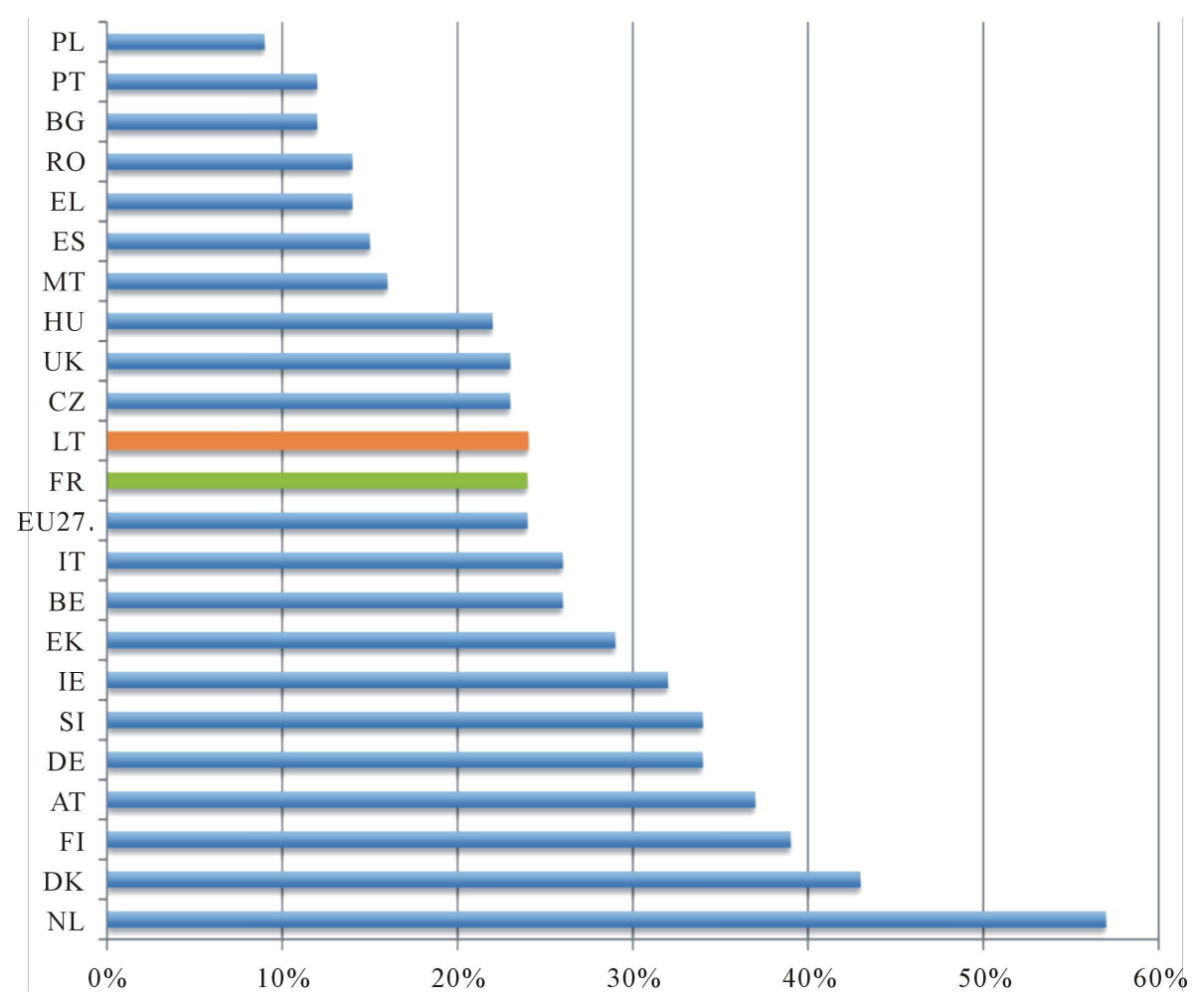

Figure 1. Rate of participation in voluntary. 
Table 3. Percentage of people aged 14 and over who has been volunteers in the interview year (percentage).

\begin{tabular}{|c|c|c|c|c|c|c|c|c|c|c|c|}
\hline \multirow{2}{*}{ Region } & \multicolumn{11}{|c|}{ Year } \\
\hline & Average 1995-2000 & 2001 & 2002 & 2003 & 2004 & 2005 & 2006 & 2007 & 2008 & 2009 & 2010 \\
\hline Piemonte & 11.2 & 11.8 & 9.9 & 11.7 & n.d. & 12.4 & 11.8 & 13.6 & 13.7 & 13.5 & 13.7 \\
\hline Valle d'Aosta & 14.5 & 14.4 & 13.3 & 14.2 & n.d. & 15 & 16.8 & 13 & 16.5 & 12.7 & 15.5 \\
\hline Lombardia & 13.7 & 13.3 & 12 & 15.2 & n.d. & 13.9 & 15.5 & 15.3 & 13.6 & 14.9 & 16.9 \\
\hline Trentino-Alto Adige & 25.1 & 24.9 & 24.6 & 25.5 & n.d. & 27.7 & 25.7 & 24.9 & 27.5 & 24.6 & 27.1 \\
\hline -Bolzano/Bozen & 28.9 & 25.8 & 26.9 & 27.7 & n.d. & 28.3 & 25.7 & 24.4 & 26.8 & 22.4 & 26.4 \\
\hline -Trento & 21.4 & 24 & 22.4 & 23.5 & n.d. & 27.1 & 25.6 & 25.7 & 28.1 & 26.4 & 27.8 \\
\hline Veneto & 15.5 & 16.8 & 16.7 & 15.9 & n.d. & 17 & 15.6 & 17.6 & 16.7 & 16 & 16.9 \\
\hline Friuli-Venezia Giulia & 13.4 & 14.8 & 12 & 13.6 & n.d. & 13.5 & 14.8 & 13.3 & 15.3 & 13.8 & 16.6 \\
\hline Liguria & 10.1 & 8.8 & 9.7 & 10.7 & n.d. & 9 & 9.7 & 10.6 & 11 & 11.3 & 11.7 \\
\hline Emilia-Romagna & 13.9 & 15.4 & 13 & 13.5 & n.d. & 14.3 & 13.5 & 16.3 & 16.3 & 15.6 & 15.7 \\
\hline Toscana & 14.2 & 17.1 & 13.5 & 15.9 & n.d. & 14 & 13.7 & 16.6 & 12.7 & 14.5 & 15.8 \\
\hline Umbria & 10.2 & 9.9 & 7.8 & 11.3 & n.d. & 9.8 & 12.1 & 9.5 & 12.5 & 11.8 & 10.7 \\
\hline Marche & 9.3 & 9.5 & 8.4 & 10.9 & n.d. & 13.4 & 10.4 & 11.1 & 9.2 & 13.6 & 12.2 \\
\hline Lazio & 6.5 & 6.6 & 7.1 & 6.6 & n.d. & 8.6 & 8.2 & 8.3 & 8.8 & 9 & 10.2 \\
\hline Abruzzo & 6.3 & 7 & 5.8 & 7.7 & n.d. & 9.4 & 6.6 & 8.1 & 8.2 & 8 & 8.3 \\
\hline Molise & 6.7 & 6.9 & 7.6 & 7.5 & n.d. & 6.4 & 6.4 & 8.6 & 9.3 & 7.8 & 9.9 \\
\hline Campania & 5.9 & 7 & 4.4 & 5.9 & n.d. & 6.7 & 5.5 & 6.9 & 6 & 6.5 & 6.5 \\
\hline Puglia & 6.9 & 7.2 & 6.8 & 7.8 & n.d. & 8 & 7 & 7.6 & 7.9 & 7.6 & 7.6 \\
\hline Basilicata & 6.6 & 8.1 & 7.8 & 8.2 & n.d. & 9.6 & 11.5 & 10.4 & 12.1 & 10.5 & 11.7 \\
\hline Calabria & 6.4 & 5.9 & 7 & 5.2 & n.d. & 6.9 & 7.1 & 6.8 & 7.3 & 7.9 & 9.1 \\
\hline Sicilia & 5.4 & 5.7 & 6.5 & 5 & n.d. & 6.3 & 6.4 & 5.4 & 5.7 & 7.5 & 7.4 \\
\hline Sardegna & 10.5 & 11 & 8.8 & 8.7 & n.d. & 9.6 & 10.4 & 11.4 & 11.7 & 10.5 & 12.4 \\
\hline Italia & 10.4 & 11 & 9.9 & 10.9 & n.d. & 11.3 & 11.1 & 11.8 & 11.4 & 11.8 & 12.6 \\
\hline Nord & 13.8 & 14.2 & 12.9 & 14.5 & n.d. & 14.4 & 14.6 & 15.5 & 15 & 15 & 16.2 \\
\hline Nord-Ovest & 12.5 & 12.4 & 11.2 & 13.7 & n.d. & 13 & 13.9 & 14.3 & 13.3 & 14.1 & 15.5 \\
\hline Nord-Est & 15.4 & 16.7 & 15.4 & 15.6 & n.d. & 16.5 & 15.6 & 17.3 & 17.3 & 16.3 & 17.3 \\
\hline Centro & 9.7 & 10.6 & 9.4 & 10.6 & n.d. & 11.1 & 10.6 & 11.4 & 10.4 & 11.6 & 12.3 \\
\hline Centro-Nord & 12.5 & 13.1 & 11.9 & 13.3 & n.d. & 13.4 & 13.4 & 14.3 & 13.6 & 14 & 15 \\
\hline Mezzogiorno & 6.5 & 7 & 6.2 & 6.4 & n.d. & 7.4 & 6.8 & 7.2 & 7.3 & 7.7 & 8 \\
\hline Sud & 6.3 & 7 & 5.8 & 6.7 & n.d. & 7.5 & 6.5 & 7.4 & 7.3 & 7.4 & 7.7 \\
\hline Isole & 6.7 & 7 & 7.1 & 5.9 & n.d. & 7.2 & 7.4 & 6.9 & 7.3 & 8.3 & 8.7 \\
\hline
\end{tabular}

Source: ISTAT.

volunteers are 26\%, a percentage just above the European average, much higher than the one resulting from the Multipurpose Survey.

We add two tables on the two countries where updated data on volunteers are available: England (Figure 2) and Spain (Figure 3). A different picture emerges, since in both countries volunteerism is shrinking: the strongest decrease is in England, but also in Spain participation in volunteers associations seem to decrease together with the decrease in working activities. 


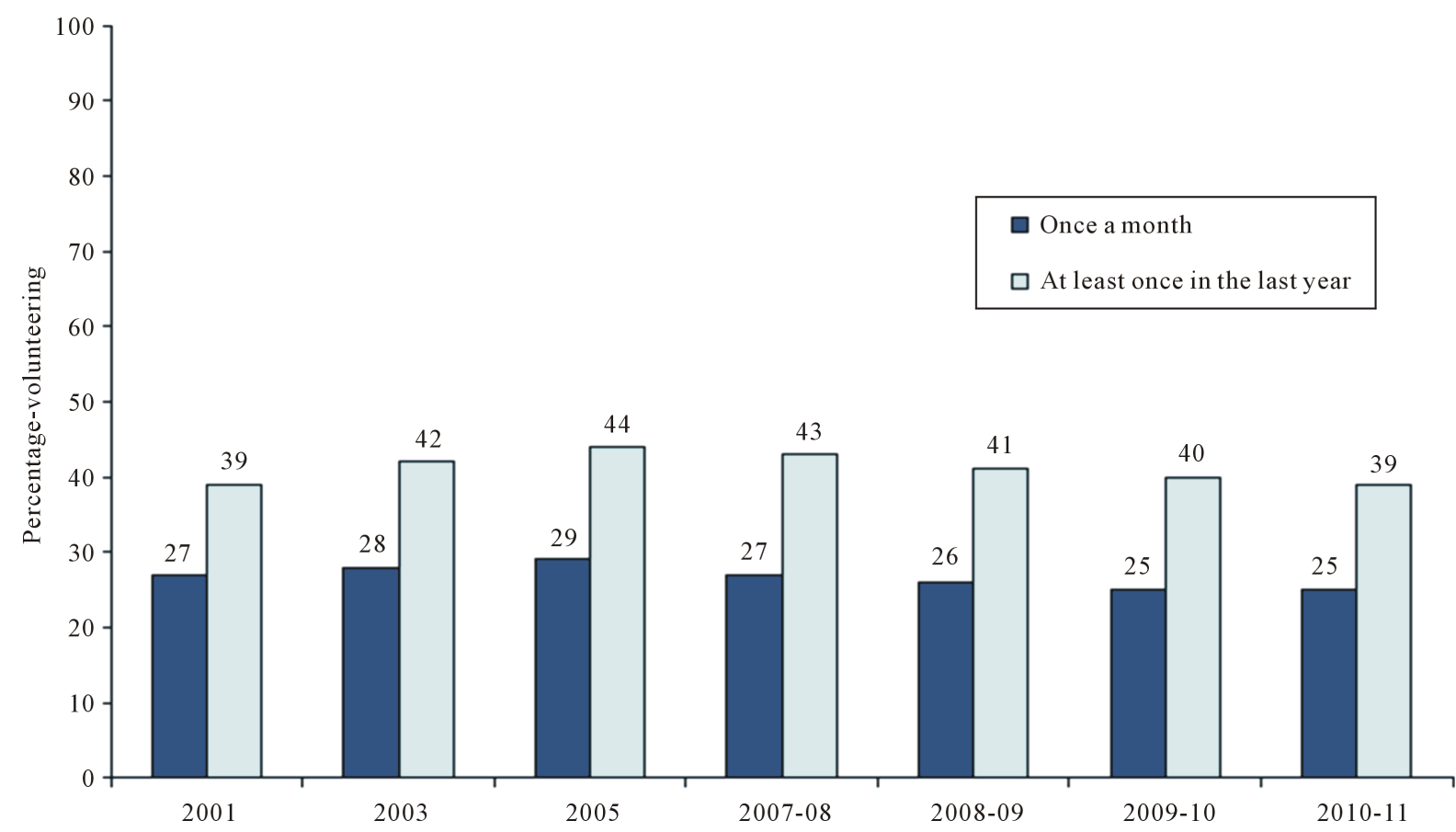

Figure 2. England: Participation in formal volunteering, 2001 to 2010-11. Source: Citizenship survey.

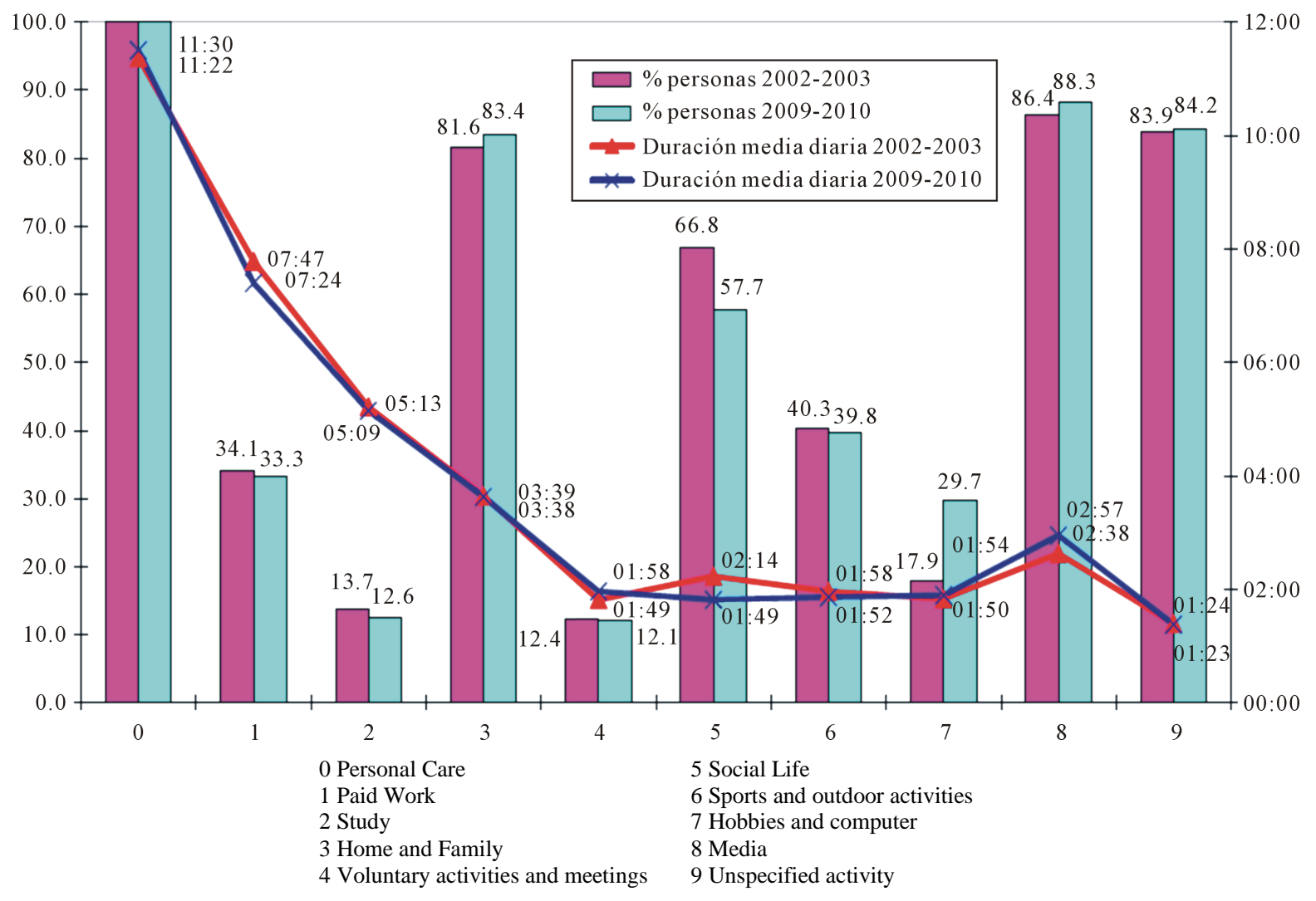

Figure 3. Spain. Percentage of people performing the activity in the course of the day and average daily activity devoted to such persons, 2002-2003 and 2009-2010². Source: Instituto Nacional de Estadistica.

\footnotetext{
2“Duracion media diaria” states for: Daily average lenght.
} 


\section{Demand for Volunteers and for Volunteers Services}

As mentioned above, the presence of volunteers in a community depends both from the individual choice of volunteering, and from the different possibilities that are offered to the individuals. Supply and demand determine the number of volunteers involved and the amount of services produced in each sector of intervention. The demand for volunteer services is more difficult to analyze, since it can manifest itself as increased demand for a service that already exists, or for a new service.

The differential amount of volunteering in different areas reflects both the supply and the demand side: at the European level volunteers are more actively involved in certain areas (e.g., sports clubs, see Figure 4). Other areas, however, especially those related to activities of clear political nature (e.g., parties, trade unions, etc.) have a lower participation rate [42] [43]. The demand for volunteers, and/or the interest of the volunteers themselves towards certain sectors depends from the characteristics of the organizations involved, and/or the type of good or service offered.

If a sports club is easier to organize, activate and maintain than an association providing assistance to people in difficulty, the sports sector demands more volunteers than the care sector. If societies characterized by a high

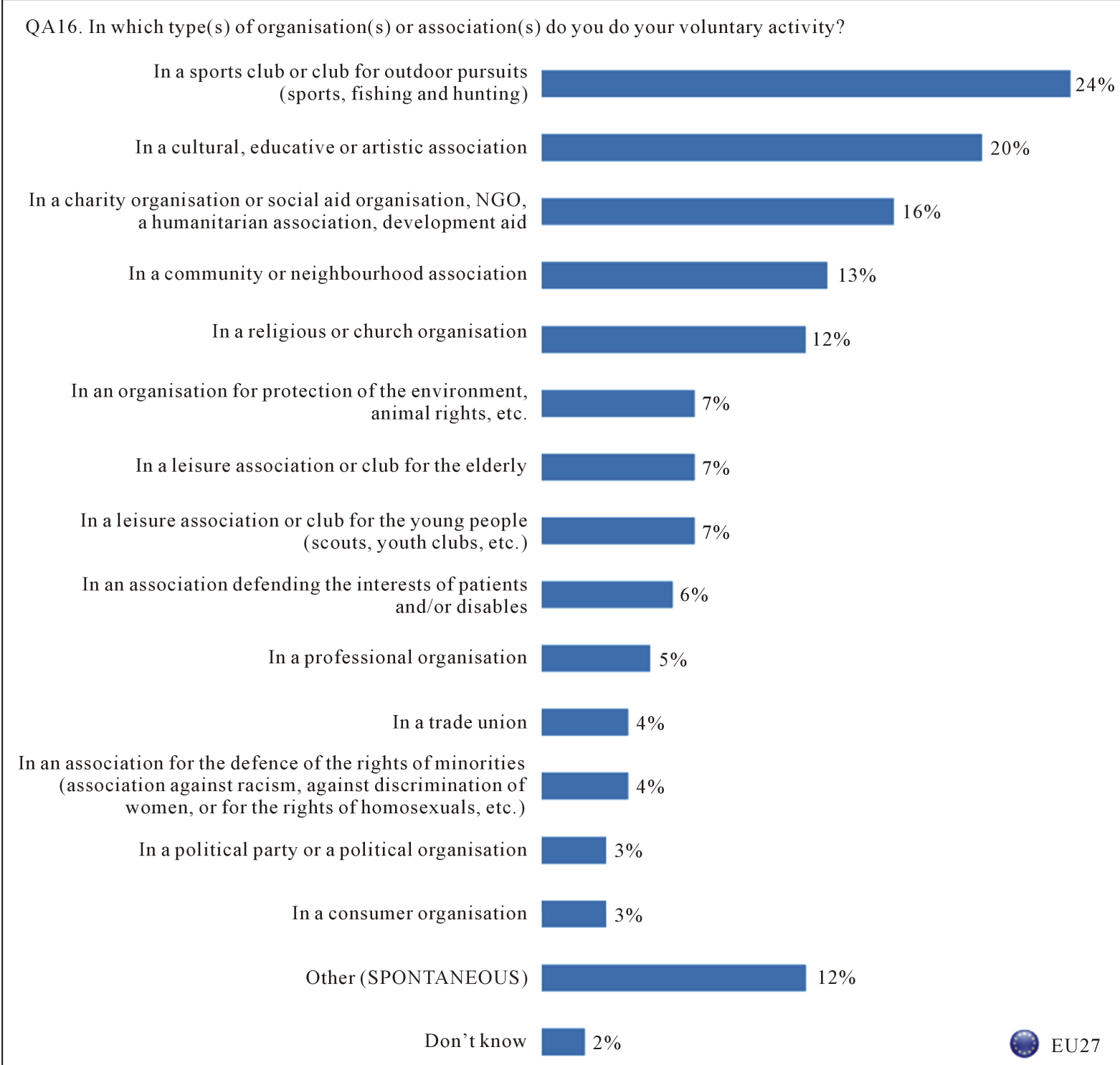

Figure 4. Fields of voluntary participations among Europeans. Source: Eurobarometer/European parliament 75.2. 
level of both economic development and labor productivity, as well as a strong tradition of democratic institutions, have a higher number of non-profit organizations, these characteristics affect directly volunteers supply as well as the demand for volunteers and the demand for [39] voluntary services. In these societies both quantitative and qualitative growth of organizations employing volunteer work is favored, thus increasing the quantity and the variety of public goods.

According to the same survey, carried on during the European year of volunteering in 2011, the areas of volunteer participation [44], and the ones in which the volunteers themselves believe volunteerism is the most important, are not the same. Solidarity, Welfare, health and the environment are in the first place in the ranking of areas which are thought to be the most important, but volunteers participate actively mainly in sport and cultural associations, NGO for humanitarian aid and neighborhood associations (see Figure 5). This discrepancy between the demand for volunteers' services and the supply of volunteers can be read as either the result of the

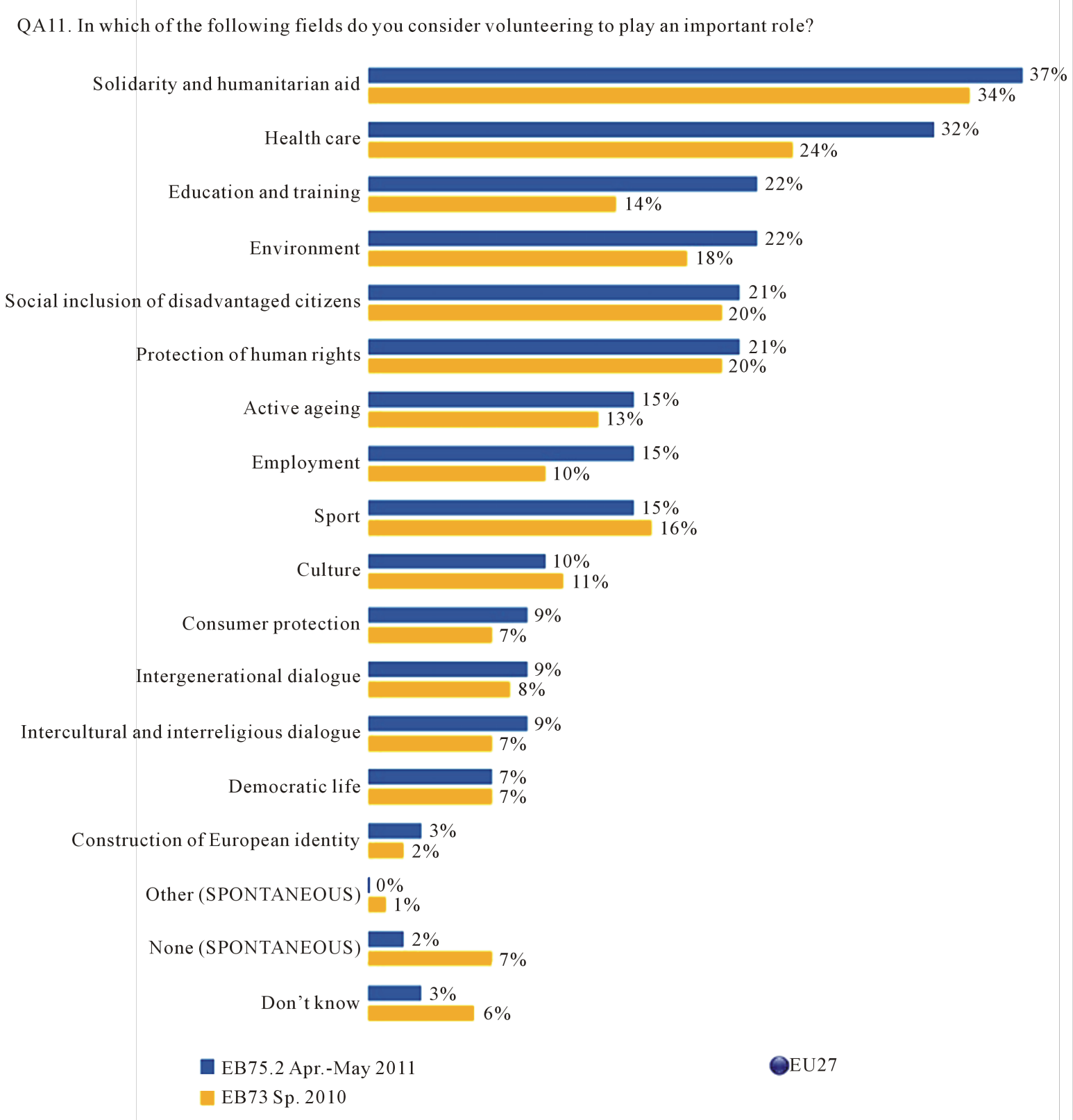

Figure 5. Most important fields for voluntary participation. Source: Eurobarometer/European parliament 75.2. 
technical characteristics of the organizations involved, or a forerunner of a future trend of demand for services, which has not yet found a sufficient supply to meet it.

\section{Conclusions}

The first evidence summarized in this study does not permit definitive conclusions, but reinforces the need to advance in the understanding of important issues. Most of them are certainly not new, but have become more urgent in the process of the ongoing transformation. What is the mix of private and public organizations in the provision of semi-public goods, i.e., goods whose consumption, although excludable and rival, has considerable positive externalities? The present recession, reducing citizens' income and state revenues can act as a natural experiment, allowing testing relevant hypotheses. Given the challenges that come from the new geo-political balance, the structural composition of production and international trade is constantly changing. Although education has probably the main role in forming the new capabilities needed in a context of increasingly rapid and intense international competition, satisfying other social needs is equally important to ensure flexibility and social cohesion. Volunteering and the Third Sector have an increasing role in improving skills and entrepreneurship, as well as potentially reducing the costs of social services and improving the state's ability to meet new specialized needs.

Volunteering, far from being an "economic puzzle", is a form of human and social capital which in recent times has enjoyed a steady increase not only in our country, but in the whole Europe, despite some exceptions. The first results of our analysis show that the crisis has not reversed this positive trend, but that the very idea of volunteering is changing.

\section{References}

[1] United Nations (2007) Handbook on Non-Profit Institutions in the System of National Accounts. UN, New York.

[2] Salamon, L.M., Sokolowski, S. and Haddok, M.A. (2011) Measuring the Economic Value of Volunteer Work Globally: Concepts, Estimates, and a Roadmap to the Future. Annals of Public and Cooperative Economics, 82, 217-252

[3] Menchik, P. and Weisbrod, B.A. (1987) Volunteer Labor Supply. Journal of Public Economics, 32, 159-183. http://dx.doi.org/10.1016/0047-2727(87)90010-7

[4] Schiff, J. and Weisbrod, B. (1993) Competition between For-Profit and Non-profit Organizations. In: Ben-Ner, A. and Gui, B., Eds., The Non-Profit Sector in the Mixed Economy, The University of Michigan Press, Ann Arbor, 288 p.

[5] Freeman, R.B. (1997) Working with Nothing: The Supply of Volunteer Labor. Journal of Labour Economics, 15, 140-166. http://dx.doi.org/10.1086/209859

[6] Tilly, C. and Tilly, C. (1994) Capitalist Work and Labor Markets. In: Smelser, N. and Swedberg, R., Eds., Handbook of Economic Sociology, Princeton University Press, Princeton, 283-313.

[7] Bollè, P. (2009) Labour Statistics: The Boundaries and Diversity of Work. International Labour Review, 148, $183-193$.

[8] International Labour Organization (2011) Manual on the Measurement of Volunteer Work. ILO, Geneva.

[9] Wilson, J. and Musick, M. (1997) Who Cares? Toward an Integrated Theory of Volunteer Work. American Sociological Review, 62, 694-713. http://dx.doi.org/10.2307/2657355

[10] Bekkers, R. and Bowman, W. (2008) The Relationship between Confidence in Charitable Organizations and Volunteering Revisited. Nonprofit and Voluntary Sector Quarterly, 38, 884-889. http://dx.doi.org/10.1177/0899764008324516

[11] Mellor, D., Hayashi, Y., Stokes, M., Firth, L., Lake, L., Staples, M., Chambers, S. and Cummins, R. (2009) Volunteering and Its Relationship With Personal and Neighborhood Well-Being. Nonprofit and Voluntary Sector Quarterly, 38, 144-159; http://dx.doi.org/10.1177/0899764008317971

[12] Prouteau, L. and Wolff, F. (2006) Does Volunteer Work Pay off in the Labor Market? The Journal of Socio-Economics, 35, 992-1013. http://dx.doi.org/10.1016/j.socec.2005.11.021

[13] Antoni, G.D. (2009) Does Satisfaction Matter? A Microeconomic Empirical Analysis of the Effect of Social Relations on Economic Welfare. The Journal of Socio-Economics, 38, 301-309. http://dx.doi.org/10.1016/j.socec.2008.07.001

[14] Giunta, G., Giunta, G. and Marino. D. (2014) A Community Welfare Model Interdependent with Productive, Civil Economy Clusters: A New Approach. Forthcoming.

[15] Andreoni, J. (1990) Impure Altruism and Donations to Public Goods: A Theory of Warm-Glow Giving. The Economic Journal, 100, 464-477. http://dx.doi.org/10.2307/2234133 
[16] Putnam, R.D. (1993) Making Democracy Work: Civic Traditions in Modern Italy. Princeton University Press, Princeton.

[17] Wollebæk, D. and Strømsnes, K. (2008) Voluntary Associations, Trust, and Civic Engagement: A Multilevel Analysis. Nonprofit and Voluntary Sector Quarterly, 37, 249-263. http://dx.doi.org/10.1177/0899764007304754

[18] Apinunmahakyl, A., Barham, V. and Devlin, R.A. (2009) Charitable Giving, Volunteering, and the Paid Labor Market. Nonprofit and Voluntary Sector Quarterly, 38, 77-94.

[19] Sundeen, R.A., Garcia, C. and Raskoff, S.A. (2009) Ethnicity, Acculturation, and Volunteering Organizations. Nonprofit and Voluntary Sector Quarterly, 38, 929-955. http://dx.doi.org/10.1177/0899764008322779

[20] Themudo, N.S. (2009) Gender and the Nonprofit Sector. Nonprofit and Voluntary Sector Quarterly, 38, 663-683. http://dx.doi.org/10.1177/0899764009333957

[21] Enjolras, B. (2008) A Governance-Structure Approach to Voluntary Organizations. Nonprofit and Voluntary Sector Quarterly, 38, 761-783. http://dx.doi.org/10.1177/0899764008320030

[22] Borzaga, C., Gui, B. and Schenkel, M. (1995) Disoccupazione e bisogni insoddisfatti: Il ruolo delle organizzazioni non-profit. Quaderni di Economia del lavoro, 50, 100-129.

[23] Musick, M.A. and Wilson, J. (2007) Volunteers: A Social Profile. Indiana University Press, Bloomington.

[24] Ishkanian, A. and Szeter, S. (2012) The Big Debate Society. A New Agenda for Social Welfare? Edward Elgar, Cheltenham. http://dx.doi.org/10.4337/9781781002087

[25] Weisbrod, B.A. (1975) Toward a Theory of the Voluntary Nonprofit Sector in a Three-Sector Economy. In: Phelps, E., Ed., Altruism, Morality and Economic Theory, Russell Sage, New York, 171-195.

[26] Matsunaga, Y., Yamauchi, N. and Okuyama, O. (2010) What Determines the Size of the Nonprofit Sector? A CrossCountry Analysis of the Government Failure Theory. Voluntas, 21, 180-201. http://dx.doi.org/10.1007/s11266-010-9125-9

[27] Vaughan-Whitehead, D. (2013) Public Sector Shocks in Europe: Between Reforms and Quantitative Structural Adjustment. In: Vaughan-Whitehead, D., Ed., Public Sector Shock, Edward Elgar Publishing, Cheltenham, 1-42. http://dx.doi.org/10.4337/9781781955352.00006

[28] Handy, F., Mook, L. and Quarter, J. (2007) The Interchangeability of Paid Staff and Volunteers in Nonprofit Organization. Nonprofit and Voluntary Sector Quarterly, 37, 76-92. http://dx.doi.org/10.1177/0899764007303528

[29] Nichols, G. and Ojala, E. (2009) Understanding the Management of Sports Events Volunteers through Psychological Contract Theory. Voluntas, 20, 369-387. http://dx.doi.org/10.1007/s11266-009-9097-9

[30] Rogelberg, S.G., Allen, J.A., Conway, J.M., Goh, A., Currie, L. and McFarland, B. (2010) Employee Experiences with Volunteers Assessment, Description, Antecedents, and Outcomes. Nonprofit Management \& Leadership, 20, 423-444. http://dx.doi.org/10.1002/nml.20003

[31] Handy, F., Seto, S., Wakaruk, A., Mersey, B., Mejia, A. and Copeland, L. (2010) The Discerning Consumer: Is Nonprofit Status a Factor? Nonprofit and Voluntary Sector Quarterly, 39, 866-883. http://dx.doi.org/10.1177/0899764010362113

[32] Marino, D. and Timpano, F. (2009) Altruism in Firms? Competition: Towards an Evolutionary Foundation of Nonprofit Behavior. International Journal of Applied Economics and Econometrics, 4, 281-289.

[33] Benjamin, E.J. (2001) A Look inside Corporate Employee Volunteer Programs. Journal of Volunteer Administration, 19, $16-31$.

[34] Tschirhart, M. (2005) Employee Volunteer Programs. In: Brudney, J.L., Ed., Emerging Areas of Volunteering, Arnova, Indianapolis, 13-29.

[35] Booth, J.E., Park, K.W. and Glomb, T.M. (2009) Employer-Supported Volunteering Benefits: Gift Exchange among Employers, Employee, Volunteer and Organizations. Human Resource Management, 48, 227-249. http://dx.doi.org/10.1002/hrm.20277

[36] Sajardo Moreno, A. and Serra Yoldi, I. (2008) Avances recientes en la investigacion economica sobre el voluntariado: Valoracion economica del trabajo voluntario, costes de gestion del voluntariado y voluntariado corporativo. CIRIECEspaña, Revista de Economía Pública, Social y Cooperativa, Decembre 2008, No. 63, 191-225.

[37] Porter, M. and Kramer, M.R. (2006) Strategy and Society: The Link between Competitive Advantage and Corporate Social Responsibility. Harvard Business Review, 84, 78-92.

[38] Zoli, M. (2004) The Welfare State Systems in European Union Countries. LLEE Working Document, Roma.

[39] Salamon, L.M., Sokolowski, S. and Anheier, H.K. (2000) Social Origins of Civil Society: An Overview. Johns Hopkins University, Baltimore.

[40] Giunta, G. and Marino, D. (2014) Impresa sociale e politiche di sviluppo e coesione nel Mezzogiorno: Lo strumento 
della fondazione di comunità. Impresa Sociale, 3.

[41] Marino, D., Michelutti, M. and Schenkel, M. (2009) The Attitudes, Motivations and Satisfaction of Volunteers. International Journal of Applied Economics and Econometrics, 17, 368-405.

[42] GHK (2011) Study on Volunteering in the European Union-Final Report. Directorate General Education and Culture, European Union, Bruxelles.

[43] McCloughan, P., Batt, W.H., Pribs, M. and Scully, D. (2011) Second European Quality of Life Survey—Participation in Volunteering and Unpaid Work. European Foundation for the Improvement of Living and Working Conditions, Bruxelles.

[44] European Parliament (2011) Special Eurobarometer of the European Parliament 75.2_-Voluntary Work. Directorate General Communication, June 2011, Bruxelles. 
Scientific Research Publishing (SCIRP) is one of the largest Open Access journal publishers. It is currently publishing more than 200 open access, online, peer-reviewed journals covering a wide range of academic disciplines. SCIRP serves the worldwide academic communities and contributes to the progress and application of science with its publication.

Other selected journals from SCIRP are listed as below. Submit your manuscript to us via either submit@scirp.org or Online Submission Portal.
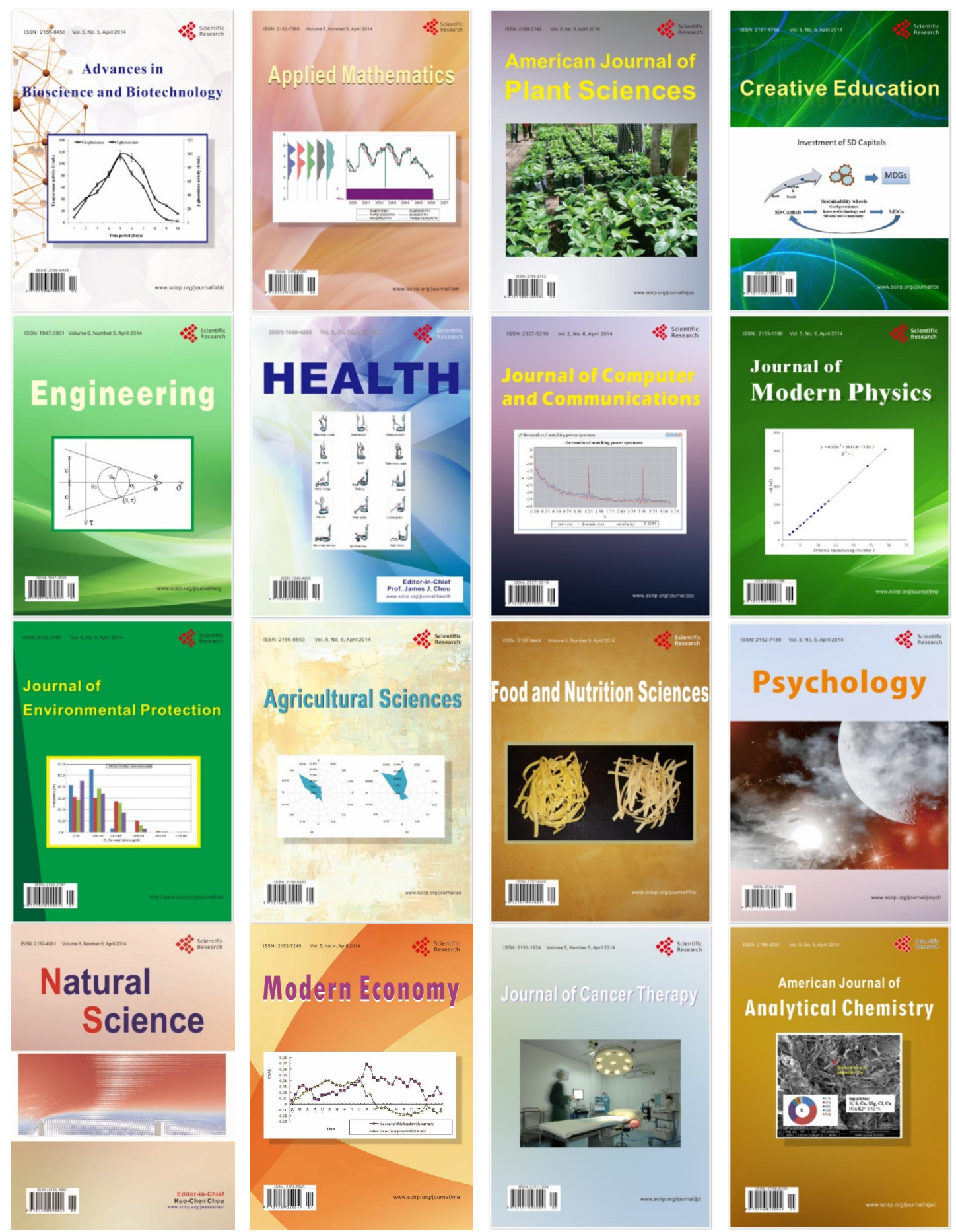